\title{
Chapter 13 \\ Mediation and Conciliation in Collective Labor Conflicts in Spain
}

\author{
Lourdes Munduate, Erica Romero Pender, Ana Belén García \\ and Francisco J. Medina
}

\section{The Case}

A transport company in Andalusia, in the south of Spain, had acquired another company, including their fleet of buses and their routes. This acquisition, following the Spanish regulations, implied the subrogation of the debts of the company, which included the pending salaries of the workers. The agreement between the new buyers and the workforce was reached through mediation, in the system for labor mediation of Andalusia (Extrajudicial System of Labor Conflict Resolution-SERCLA) where the manager decided to pay off the debt in installments. However, after a long period of time, the manager stopped paying the pay checks, which created a collective conflict.

Another mediation session took place at SERCLA with a mediation team composed of four people, two appointed by the trade unions and two appointed by the employers' organization, following the formal procedure for mediation teams in this system. The workers and the manager were present for the session. The atmosphere was tense, since the workers had not been getting paid for more than two months. The manager explained that the delays were due to a payment he had to make to social security, and he tried to keep a conciliating tone, admitting to the debts he had been accused of. Nevertheless, this was not enough to calm down the atmosphere. The president of the mediation commission asked everyone to respect the intervention turns. The manager offered to pay a large part of the debts immediately, but part of these in installments during the following months.

The mediation team invited the parties to make a recess to consider the presented proposal and used the opportunity to carry out a caucus with each

L. Munduate $(\varangle) \cdot$ E. R. Pender · A. B. García · F. J. Medina

University of Seville, Calle Camilo José Cela, s/n, 41018 Seville, Spain

e-mail:munduate@us.es

(C) The Author(s) 2019

M. Euwema et al. (eds.), Mediation in Collective Labor Conflicts, Industrial Relations

\& Conflict Management, https://doi.org/10.1007/978-3-319-92531-8_13 
party. The mediation commission also met, and they had the shared opinion that the manager had shown his resistance point too fast, giving the workers the impression that he had solvency to actually pay all debts at once. Thus, they would not agree to his proposal. When they came back from the caucus, the workers threatened to go on strike and the atmosphere became even tenser. To bring tensions down and bring the mediation back on track, one of the mediators of the commission asked people to keep calm and started to write the proposals and alternatives on a flipchart, calling the attention of both parties. They also reassured both parties that they were doing it correctly, making proposals and making progress. The workers asked to intervene and a calmer dialogue took place, with an exchange of opinions and reaching a different proposal to the initial one they had in mind.

After the dialogue, the negotiation, and the last recess, the manager accepted the proposal and they reached an agreement, avoiding the strike and allowing the workers to receive the salaries they were owed.

\subsection{Introduction}

To understand the current agglomeration of mediation systems for collective conflicts in Spain, we need to recall some historical milestones. During the dictatorship era (1939-1975), the economic model combined growth with poor labor and social conditions, and high inequalities in terms of class and gender, as well as low trust between employers and employees (Miguélez \& Prieto, 2009). The freedom of association and the right to carry out representative actions in organizations was forbidden, with the absence of Unions and collective bargaining as a consequence (Munduate, 1993; Munduate, Ganaza, Alcaide, \& Peiró, 1994). Conflicts between workers and companies were dealt with violency and with great distrust between parties. In fact, employee representatives' (ERs) recognition in Spain is one of the youngest in Western Europe, and the tradition of adversarial and confrontational relations generated during the Franco era is still present in some aspects (Elgoibar, Munduate, Medina, \& Euwema, 2012).

The Spanish transition towards democracy at a time of deep industrial restructuring (1975-1982) settled powerful reforms (Sánchez-Cuenca \& Aguilar, 2009), regarding economic measures, freedom of association, and workers' rights. Social dialogue became a socioeconomic governance mechanism during the country's return to democracy with the introduction of some important laws, such as The Spanish Workers' Statute of 1980, which established the workers' rights and promoted a collective bargaining model.

Collective bargaining in Spain has some singular characteristics: (a) collective agreements have consequences for all workers regardless if they are a part of a 
union or not; (b) collective agreements are laws, protected as any other law by the judicial system. These particular measures were adopted to strengthen the role of the unions, as representatives of the workers, and the role of collective bargaining, as a mechanism to guarantee labor rights. These measures were adopted consensually to strengthen the unions' side, which had become weak after the dictatorship.

Other mechanisms to balance power between the negotiating parties in Spanish labor relations were: ultra-activity and extension. Ultra-activity means that all collective bargaining agreements remained active unless both sides agreed to their renegotiation. If the period of an agreement finishes without a new contract, the old one remains in force. Extension means that sectorial agreements (education, tourism, health or others) automatically applied to all firms within this sector and geographical range. This characteristic also increased the relative power of unions in the collective bargaining processes.

The extension rule explains that, until 2012, although the majority of collective agreements were produced at a company level, the agreements negotiated at provincial or national sector level affected the majority of people. In summary, three key aspects are worth mentioning regarding this rule: (a) despite most of the collective agreements being carried out inside organizations, these affect a small number of workers, being sectorial agreements those with highest impact; (b) sector agreements are usually negotiated by provinces, therefore an organization with different locations has different collective agreements and different labor conditions (which is another source of conflict between parties); (c) the configuration of the agreements by provinces does not fit the configuration of the state as it currently is, by autonomous regions.

The legal intervention of the different governments during the last crisis period has produced changes in the structure of the collective bargaining in Spain. The socialist government (2008-2012) introduced a series of legal reforms to encourage companies introducing negotiated flexibility measures instead of recurring to downsizing. This reform allowed companies with economic difficulties to set limits to sectorial collective agreements through different flexibility measures, including temporary salary reductions. The subsequent reform of the conservative government (Partido Popular) in 2012 incremented the power of employers over unions through different actions: (a) it allowed employers to unilaterally leave the collective agreement; (b) it allowed permanent changes in working conditions (as salary or downsizing), not only for financial reasons but also for organizational, technical or productive reasons; (c) it erased ultra-activity, meaning that if two parties do not reach an agreement, the previous agreement is only valid for a year, and it eliminated the extension of the agreement, meaning that the company can currently negotiate its own agreements over or under the sector agreements; (d) collective negotiations were centralized, thus the topics to be negotiated at all levels can be decided at national level. Summarizing, this reform favored company-specific collective agreements.

Regarding social conflicts in Spain, during the past recent years there has been a decrease in the number of conflicts and strikes. In the reports of the Spanish economic and social council it is stated that the number of strikes has gone down to minimum 
levels (CES, 2017). The controversial topics are still related mostly to salary, followed by working times, restructuring, and reclamations of union rights.

There are different mechanisms to manage collective conflicts in Spain. We must first differentiate between the systems regulated by the national government by law and those extrajudicial mechanisms of conflict resolution regulated by the collective bargaining (regional or autonomous origin). An example of the national system is the Center of Mediation and Arbitration (CMAC), with offices all around Spain. Although the word 'mediation' is present in the name, the CMAC does not provide conciliation or mediation. The CMAC is only an administrative step previous to court. The parties are attended by public staff that registers their presence as a requirement previous to court proceedings. Conflict parties can attend one system or another in function of the type of conflict. CMAC is especially active for individual conflicts, whereas autonomous systems manage collective conflicts. An example of an autonomous system is the Extrajudicial System of Labor Conflict (SERCLA), in Andalusia.

\section{The Geometry of Mediation. The 3-R Model}

For the analysis of the different mediation systems in Spain, we use the 3-R model, presented in Chap. 1, as a heuristic model considering the social, legal, and organizational context in which mediation takes place. We analyze the mediation systems in Spain from the perspective of these three dimensions. Explicit attention is paid to the constraints stemming from the context (Regulations) as well as the competitive versus cooperative nature of the relationship (Relations).

\subsection{Regulations and Characteristics of the Systems}

The legislative framework states that if a conflict is of national nature, because parties in conflict belong to different autonomous regions, this conflict should be managed at the SIMA Foundation (Servicio Interconfederal de Mediación y Arbitraje). This institution is a joint foundation composed of the most representative employers and union organizations of the state (CEOE, CEPYME, CCOO and UGT). It is a public national foundation controlled by the Ministry of Work and Social Security. In Andalusia, the equivalent system is the SERCLA, which manages conflicts where the parties in conflict belong to the Andalusia region.

Mediation in Spain is considered a full mandatory process, that means that it is a voluntary process to decide to not continue with the judicial systems, but it is mandatory as a prerequisite to go to the court. SERCLA can intervene to manage collective conflicts in Andalusia using either conciliation-mediation or mediation. There are several equivalents of SERCLA in other autonomous regions; however, we focus here on the Tribunal of Labor Conciliation, Mediation and Arbitration of Catalonia (TLC) given its relevance.

As with the other autonomous regions, the TLC was created following an agreement between parties in 2005, in this case between the unions UGT and CCOO, 
Table 13.1 Systems for mediation in collective labor conflict in Spain

\begin{tabular}{l|l}
\hline Autonomous region & Mediation system for collective conflict \\
\hline Andalucía & $\begin{array}{l}\text { Sistema Extrajudicial de Resolución de Conflictos Laborales de } \\
\text { Andalucía (SERCLA) }\end{array}$ \\
\hline Aragón & Servicio Aragonés de Mediación y Arbitraje (SAMA) \\
\hline Principado de Asturias & Servicio Asturiano de Solución Extrajudicial de Conflictos (SASEC) \\
\hline Islas Baleares & $\begin{array}{l}\text { Fundación Tribunal de Arbitraje y Mediación de las Islas Baleares } \\
\text { (TAMIB) }\end{array}$ \\
\hline Islas Canarias & Tribunal Laboral de Canarias (TLC) \\
\hline Cantabria & Fundación para las Relaciones Laborales de Cantabria (ORECLA) \\
\hline Castilla y León & Servicio Regional de Relaciones Laborales (SERLA) \\
\hline Castilla La Mancha & $\begin{array}{l}\text { Jurado Arbitral Laboral de Castilla La Mancha (JURADO } \\
\text { ARBITRAL) }\end{array}$ \\
\hline Cataluña & Tribunal Laboral de Cataluña \\
\hline Euskadi & Consejo de Relaciones Laborales (CRL-LHK)-PRECO \\
\hline Extremadura & Fundación de Relaciones Laborales de Extremadura (FRLEX) \\
\hline Galicia & $\begin{array}{l}\text { Acuerdo sobre Solución Extrajudicial de Conflictos Colectivos de } \\
\text { Trabajo (AGA) }\end{array}$ \\
\hline Comunidad de Madrid & Instituto Laboral de la Comunidad de Madrid (ILM) \\
\hline Región de Murcia & Oficina de Resolución de Conflictos Laborales (ORCL) \\
\hline Comunidad Foral de & Tribunal Laboral de Navarra (TLN) \\
\hline Navarra & Tribunal Laboral de La Rioja (TLR) \\
\hline Ca Rioja & $\begin{array}{l}\text { Fundación Tribunal de Arbitraje Laboral de la Comunidad } \\
\text { Valenciana (TAL) }\end{array}$ \\
\hline Servinidal & Serio Interconfederal de Mediación y Arbitraje (SIMA) \\
\hline
\end{tabular}

and the employers' association. The parties freely decide if they take the conflict to conciliation or mediation with the TLC. The TLC can act for both collective and individual conflicts. Unlike the SERCLA, the TLC has three possibilities: (a) Conciliation, which in this system is considered facilitation without proposals by the mediators; (b) Mediation, where mediators can make proposals to the parties; and (c) Arbitration, where the third party makes a proposal that the parties must accept obligatorily.

A list with the collective mediation systems in Spain appears in Table 13.1.

The autonomous systems can intervene to manage collective conflicts using conciliation, mediation and arbitration for:

(a) Right conflicts: conflicts regarding the interpretation and application of judicial norms, collective agreements, practices, and organizational agreements or conflicts previous to legal proceedings, both perceptive and voluntary.

(b) Interest conflicts: conflicts that result from the collective negotiation processes or conflicts that cause threats of strike. 
The use of arbitration is anecdotal, as it is used for less than $1 \%$ of all the collective conflicts.

\subsection{Relationships. From Confrontational Relationships to the Promotion of Social Dialogue Between Social Partners}

In the general introduction we have seen the major structural changes produced in collective bargaining in Spain. The dispute resolution instruments used when the collective bargaining fails are derived from agreements between the parties involved in the conflict. This is important because they are not systems that are legitimated by a law or a government decision, but an agreement between the parties in conflict. In this sense, since the 90s, different Employments and Collective Agreements have been signed by the national employer associations (the CEOE) and the two dominant national unions (CCOO and UGT). These agreements provided guidance rather than binding rules for negotiation of sectorial and firm-level agreements, and allow for different mediation systems to exist throughout the country.

In this sense, we find different mediation systems acting on collective conflicts, sustained by different agreements between business associations and union associations. Each of these agreements has its own characteristics regarding the composition of mediation teams, the professionalization of the role, and the intervention procedures. This chapter focuses, especially, on one of the Autonomous systems in Spain (the SERCLA), where there is a high number of companies and population. However, we will also show some data from the national system (SIMA), as well as the Catalonian system.

\subsection{Roles. Characteristics of the Mediators' Role}

In the previous section, we have concluded that there are different mediation institutions in Spain, and that they each have their own profile in mediation interventions. The mediation at the SIMA is carried out preferably by one person, though it can be a co-mediation if the parties ask for it. The SIMA facilitates a list of proposed mediators (about 200) agreed upon by the parties that signed the SIMA agreement. The mediators are senior professionals related with the labor's law, universities, or staff from the public administration. The party that applied for the mediation has to propose a mediator from the list in their initial application document. The other party can either agree to the proposed mediator or propose a different one from the list. If both parties agree with the proposed mediator, this person will be the only mediator in the sessions. If they do not, the mediation will be carried out by two 
people. If none of the parties has assigned a mediator in the following three days after the application, these actions will be filed.

It is a free service. There is no established process for the mediation itself, thus, mediators can act with discretion. In 2016, $43 \%$ of the mediations were carried out individually, and the rest by a team. The duration of the mediation process was of 2 hours on average, and took between one and two meetings. Some complex mediation processes require weeks or even months, but others can be managed in less than an hour. Seventy seven mediators intervened in collective conflicts in 2017 (SIMA, 2017).

In SERCLA, the mediation service is provided by a mediation team that is usually composed of four mediators. A genuine characteristic of SERCLA's system is that trade unions and employers' associations design a list of eligible mediators each year. Therefore, in each mediation, two of the mediators are appointed by the main employers' association, and the other two by the two largest trade unions' lists, one appointed by each of them. The parties do not choose the mediators, they are proposed by the unions and employers' associations. Most of the people who were interviewed for this study were satisfied with this procedure of mediators appointed by the representing organizations. Both the parties and the mediators believe it is a useful solution to overcome the lack of trust between parties and the lack of mediation culture in Spain. As pointed out by a HR manager who had participated in several collective mediations:

In my experience, it is rare to notice a bias from the mediators influenced by the organization that appoints them. Actually, I think the system mostly works well this way, we know that there's balance, so we don't have to worry about a mediator taking sides.

The presidency of the Conciliation-Mediation commission rotates annually between the unions' side and the employers' side. Additionally, every mediation is also assisted by a Secretary provided by the Andalusia Government. The role of this Secretary is registering the minutes and writing the reports that the parties need to start the judicial procedure. Although the role of the Secretary is only to register these issues and to provide support, research and active observation has shown that, in some cases, they use a more active approach, analyzing the legality of the agreements or even pushing parties to continue with the negotiation when an impasse exists. As a pilot project, the staff of the SERCLA has been supporting parties in complex collective bargaining through a process of preventive conciliation.

To start mediating at the SERCLA, new mediators must follow a basic training in mediation. The SERCLA offers compulsory mediation training throughout the year, differentiating between basic and expert training. The SERCLA also organizes a general meeting each year to improve competences and develop a reflexivity process with their mediations. The requirements to become a mediator are: to follow twelvehour theoretical and practical mediation training, and to attend at least three real mediations as an observer. Once the mediators are included in the system, registered in this list, they shall take a re-training at least once every two years during their career as mediators. The SERCLA also has published a Guide for mediation as 
Table 13.2 Global data from TLC (Catalonia) and SERCLA (Andalusia) in 2016

\begin{tabular}{l|l|l}
\hline & TLC & SERCLA \\
\hline Number of conciliation/mediation & 579 & 670 \\
\hline Average time dedicated to mediation & $2 \mathrm{~h}$ & $1.76 \mathrm{~h}$ \\
\hline $\begin{array}{l}\text { Employees affected by mediation } \\
\text { agreements }\end{array}$ & $5,179,349$ & 540,188 \\
\hline Agreement rate & $40 \%$ & $40 \%$ \\
\hline
\end{tabular}

a basic resource for the training of new mediators (Munduate, Butts, Medina \& Martínez-Pecino, 2014).

The training for mediators is based on Ury, Brett, and Goldberg's model (1988) and the Slakieu (1996) approach for managing disputes. The SERCLA developed different workshops to train mediators in mediation tactics to reduce the level of conflict and understand the interest of the parties (e.g.: formulating open questions, re-framing, using words to reduce emotional levels, among others).

In the TLC, collective labor conflicts are also mediated with teams of four mediators appointed by the organizations of the foundation, in the case of conflicts in organizations with more than 30 employees. For organizations with less than 30 employees, mediations are carried out by two mediators. The percentage of collective mediations presented before the TLC which end in agreement between the parties is above $40 \%$, and those previous to strike present slightly higher chances of reaching agreement. Table 13.2 presents some key aspects comparing SERCLA with TLC.

\subsection{Description of the Mediation Process}

In the SERCLA system, the mediation starts with the application of one person or institution. In conflicts previous to strike, mediation shall be requested by the Strike Committee. Once the application form is received at the SERCLA, they will notify the parties involved and will call them, usually within the following 7 working days from the reception of the submission or the rectification of it. In general, if no agreement is reached within 25 working days the proceedings will be classified finished without agreement. In mediations previous to judicial procedures and mediations of individual conflicts (which are also a mandatory step of the judicial individual procedure), limitation periods for filing the lawsuit before the employment tribunals are suspended. This is one of the requirements established by the European Directive on Civil and Commercial Matters (SERCLA, 2014).

SERCLA has developed a Reference Model for Mediation that we present in Fig. 13.1. The first stage (Mediation team pre-meeting to prepare the session), is oriented to the mediators' preparation as a team. In order to ensure cooperation within the team and that the parties perceive them as such, coordination is essential. Mediators are appointed by the parties (unions and employers associations). Mediation is based in a joint meeting although a caucus is possible in some circumstances (e.g.: 


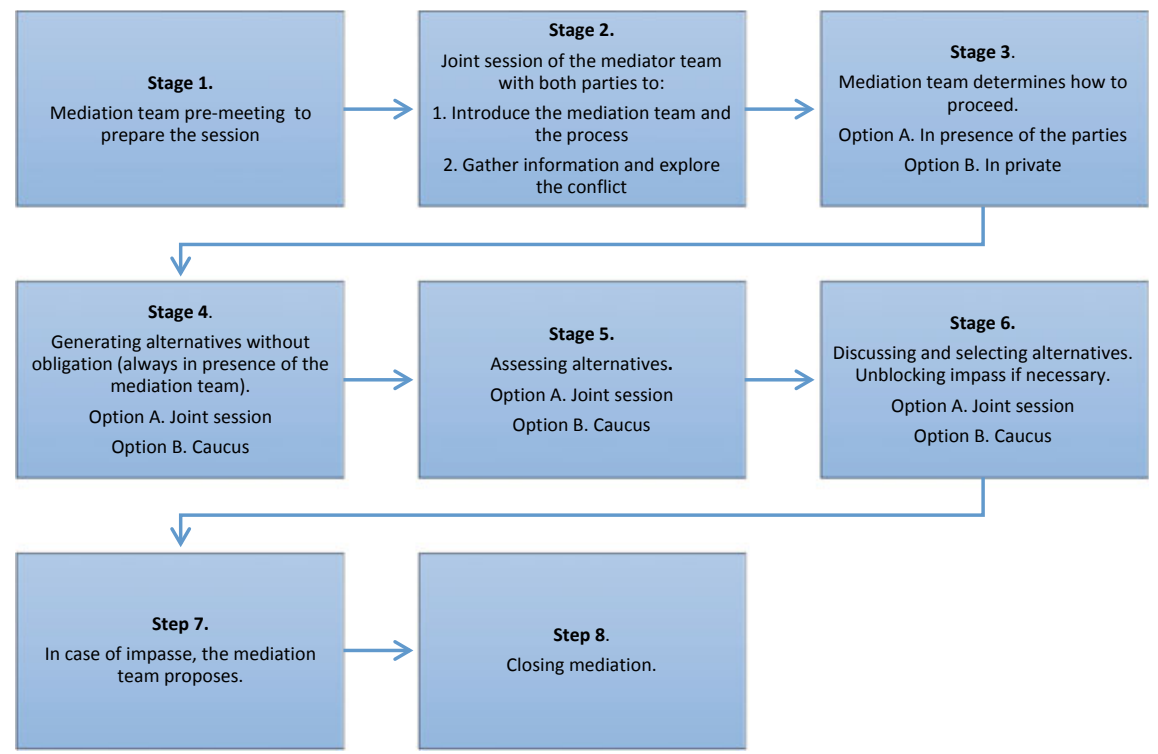

Fig. 13.1 Mediation model in SERCLA (Andalucia, Spain)

cases of violence). The Mediation committee coordinates, before each mediation, in order to maintain the impartiality and prepare the strategy of the team. They can also have private meetings during the mediation process to discuss the conflict at the table, the criteria or even to elaborate proposals for the parties.

As mentioned before, a challenge at the SERCLA is that Employers and Employees' associations decide what specific mediators will mediate, before each mediation. There are no stable mediation teams, which often hinders the coordination among mediators. A possible solution is a selection of the mediators based on competences, suggested both by the parties and the mediators. There is a debate around making teams stable, as some mediators in the system think this would be more effective. Following a statement by a mediator:

I notice that when I've repeated in a same team, and especially if this team is configured in a balanced way in terms of experience and knowledge, everyone gets to know their role and the results are better. I think it would help to establish stable teams, if not fully stable, at least during a period of time or for certain conflicts.

However, this perception is not shared by everyone at the SERCLA and from the interviews, it was observed that there is a mixed opinion on this matter.

Data from observations show that mediators follow the mediation model that appears in Fig. 13.1, they employ caucus less than 10\%, and prefer a joint session. They usually follow recommendation from training courses about the use of different mediation techniques. SERCLA does not formally distinguish between mediation and conciliation, observational data suggest that they follow a conciliation process. 
Mediators also recognize the importance of the SERCLA's secretary role. They consider this role as a crucial for mediation for different reasons: the secretary can play a different role than mediators without losing neutrality and impartiality, for example, pushing parties to negotiate or advise parties about the legal consequences of their positions. The secretary also has the role of writing the agreement. In this sense, they recently changed between writing the agreement in a separate office to writing the agreement in the same session in presence of the parties. It has been proven that writing the agreement during the mediation process, and checking it with the parties, increases agreement rates. As pointed out by one of the mediators at SERCLA:

We put quite some effort into writing out the minutes of the session and the agreement.

Though the mediation team and the secretary here have the leading role, we like to keep the parties involved in the process, I feel that this helps them to keep to the agreement and reach a common understanding of what has happened during the session.

Another important point is that parties do not perceive loss of neutrality or impartiality in the mediators based on the belongingness to the professional association or to the unions. Moreover, parties in some cases defend this system configuration because they trust in one system where they actively participate.

It is interesting to note that these mediators know that they should not make proposals and have received training in that regard. However, they recognize that they are often making proposals.

Some heterogeneity in mediation's competences is founded between and within mediation teams. They ask for more training in complex competences and for more stable mediation teams. As stated by one of the providers of the system:

Though we would like to provide more training to our mediators, both new and experienced, it is difficult. There are 450 mediators in our system, and also the responsibility for training the mediators actually lays in the organizations that appoint them. We are thinking of additional solutions, like increasing the number of observations for new mediators.

The more challenging part of the process is the coordination within mediation teams. They have a formal designation of the presidency, but the coordination of the different roles for the mediation is not clear. SERCLA recommend mediators to stay in the room about twenty minutes previous to the mediation. In our observation experience, mediators stay in the room waiting parties, but they usually do not discuss about the case or about the coordination roles.

SERCLA has some appropriate room for the joint sessions and also possibilities for caucus. They have a flipchart and encourage mediators to use this tool, but the use of flipchart in mediation is low.

SERCLA has an internal process of revision of the mediation process, making clearer the different stages and discussing with mediators the introduction of a process of mediation with proposals. The final outcome of this process is a new mediation model with a high consensus of the Andalusia mediators.

In the TLC system (Labor tribunal of Catalunya) the parties may find three possibilities: conciliation, mediation, and arbitration. The difference between conciliation and mediation is that the mediators can elaborate a proposal, which could be accepted 
by parties. In case the conciliation process would not end up in an agreement, the parties can choose to start a mediation process, as long as this one starts in the following three days. Once the TLC's Mediation Commission is formed, the commission must have at least a mandatory joint meeting with both representations. After this joint meeting, the mediators can encounter each party separately (as long as neutrality is assured).

If the parties also cannot reach an agreement after the mediation, the Mediation Commission must then dictate a mandatory proposal that will be given to both parties so that they can study and reply on it, globally and without options of partial modification, after a recess or latest $24 \mathrm{~h}$ after the session. This proposal must be agreed upon and justified by the mediators, without any intervention from the parties. Once the proposal has been accepted by both parties, the mediation act can be considered as finalized with agreement. If, on the other hand, one or both parties would not accept the agreement, the mediation would finalize without agreement and the Commission would make sure the final positions of the parties are gathered. In both cases, the mediators' proposal is kept record of. This mediators' proposal can only be accepted integrally, not partially or with exceptions or modifications, unless both representations agree upon these, as a starting point of the agreement.

\subsection{Effectiveness of the System. Evaluation by Stakeholders}

The first fourteen years of the SERCLA have shown a significative effectiveness. Approximately 13,400 conflicts have been submitted, affecting more than 400,000 companies and more than 3000,000 employees (Medina, Vilches, Otero, $\&$ Munduate, 2014). It is noticeable that not all cases submitted to SERCLA have been finally processed; this can be for multiple reasons (SERCLA, 2014). Often the claimant desisted from the conflict, or the strike was cancelled, or the defendant did not show up in the mediation session (this is particularly the case in the public sector). The number of failures has shown to be higher for conflicts in the public sector than in the private sector. If we compare percentages of agreements between types of conflicts, a substantial difference is appreciated. Conflicts of rights get lower settlement rates than conflicts of interest, as seen in Fig. 13.2.

The level of agreements reached by interventions through TLC in the period between 1992 and 2015 was $60 \%$ in the case of mediations, and 52\% in the case of conciliations. In this period, 1164 interventions of conciliations/mediations took place, 53, 10\% of strikes were called off, and an estimated 25 million euros were saved through the recovered strike hours. The mediation process started in 2006 as a pilot experience.

In addition to a reached agreement, another performance indicator for conciliation and mediation is the satisfaction by the parties using the system (Bollen \& Euwema, 2013). We analyzed systematically the satisfaction level during the period Decem- 
ber 2017 to April 2018, based on 25 mediations. Parties and mediators reported a medium-high level of satisfaction of the mediation. Two interesting results are worth pointing out: (a) a significative high evaluation by the company representatives compared to the mediators and unions, (b) internal differences in unions in the level of satisfaction with SERCLA.

A deep analysis about the perception of mediators demonstrated a high satisfaction level in all the analyzed criteria. The most positive aspect is the quality of the system and cohesion between mediation teams. The less positive is the trust in the implementation of agreement by parties and the relationships between parties after mediation. Mediators showed their concern for various aspects: (a) Firstly, for mediation in the public sector, since agreements were reached through mediation in less than $10 \%$. The main reason is that the negotiators from the public sector cannot have the possibility to reach agreements without the government's permission, due to the restrictions of the economy. (b) They consider that they need more training to manage parties when the negotiation range is low, or parties do not like to negotiate, what usually happens in the mediations with agents (e.g. lawyers), (c) They usually claim that mediation teams are permanent, (d) more promotion of SERCLA in society, and (e) more economical resources.

\subsection{Challenges for the Spanish Systems. Qualitative Analysis of the Parties and Mediators' Perspective}

There is a social debate over what would be the best approach to adopt by the different mediation systems in Spain. We will group the issues involved according to the three dimensions derived from the 3-R model referred to previously.

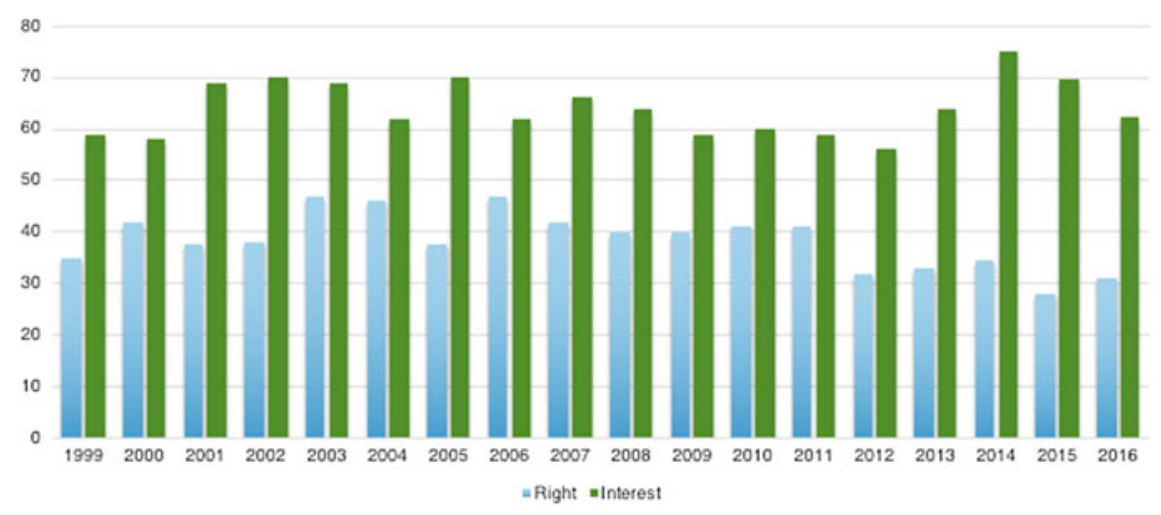

Fig. 13.2 Mediation effectiveness in conflicts of rights and of interests (SERCLA) 


\section{Regulations}

- Some new laws related to mediation and promoted by the government in the past years are especially worrying the union organizations. As said before, some mediation systems in Spain are autonomous, which means that they are outside of the government's influence. However, the latest laws in this respect establish that public foundations must be controlled by governments, implying by this that many mediation systems that are foundations -such as SIMA- are currently under the Government's control.

- There is a great diversity in how the mediation processes are carried out. While some of them (e.g.: SERCLA \& TLC) have systematized their mediation protocols with very detailed descriptions of the process, other systems do not give recommendations or hardly establish any procedure.

- A detailed analysis of mediations in conflicts of the public sector is deemed necessary, since the organizations are very constrained by the existing labor legislation and they attend the mediation process without any possibility to negotiate, or simply do not show up at the mediation meeting.

\section{Relations}

- There is an important debate going on about how to improve the mediation procedures to increase trust between the parties. The unions' side believes that often the employers' side attends the mediation with hardly any interest in negotiating or gives the lawyers that represent them very strict instructions, so they leave little room for reaching satisfying agreements for both parties.

Roles

- The autonomous systems and the mediators that were originally designed and appointed for collective conflicts are increasingly taking on more competencies and mediations in individual conflicts. For example, individual conflicts involving sanctions will be taken on by the SERCLA in the following months, while they used to be managed by the CMAC. These new issues will entail deliberations for the systems about the procedures and techniques of mediation used by the mediators, which will have to be adapted to the new types of conflict. It will also mean an increase in the activity of these systems and thus a need for more resources.

- There is also a debate regarding if mediators should make proposals to the parties or not. The differentiation between mediation and conciliation in the TLC has laid the cards on the table for new possibilities of distinguishing between mediation as a strict form and mediation as a procedure which can start as a mediation but if it reaches an impasse, a proposal can be made by the mediators, which could be accepted by the parties (or not). This mixed system of mediation and proposals of the mediators increases the effectiveness of the mediation, following the records of the TLC.

- There is a national debate about the training of mediators and arbitrators in the different mediation systems. In Spain, mediation in collective conflicts is still relatively an "amateur" process, where some of the mediators come from the 
parties themselves and in other cases they are public service workers related to labor conflicts (e.g.: university staff, work inspectors, etc.). In the same line, training on integrative negotiation is required as important for parties and mediators.

- There is also a need for analyzing the records written by the mediators, in such that they also reflect the attempts to negotiate by the parties, the key points covered in the mediation, as well as the aspects observed by the mediators which have led to an impasse (if there were any). Records with more qualitative information could facilitate learning from the mediations, as well as systematizing good mediation practices and their promotion.

- It is important to increase institutional resources: better and more meeting rooms, larger time available for mediation, better trained mediators and deeper, and more specific taylor made training in general.

- In the same direction, it is important to disseminate the existence and effectiveness of the different available systems of Mediation in Collective Conflict. The achievements of the different systems described before are very high and, if the citizens knew about these, it would improve the credibility of the systems and society's trust in them, in addition to creating awareness of the need of better resources for their further development.

- There is an ongoing debate about the need for a greater professionalization of the mediation systems, though not necessarily of the mediators. The creation of stable mediation teams, the appointment of mediators to conflicts according to their specific competences, the incorporation of selection, training and evaluation systems based on competences, are all measures that are currently being analyzed by some of the Spanish mediation systems.

\subsection{Conclusions}

Spain is a clear example of how the mediation systems can be explained in relation to the Regulation of the political and normative system, as it has been expressed by some mediation models like the 3-R model (Bollen, Euwema, \& Munduate, 2016). In this sense, the Spanish constitution establishes autonomy for collective negotiations, and thus also for the mechanisms of labor conflict resolution. These aspects explain why the government cannot directly regulate specific aspects of collective conflict mediations without risking this constitutional act. This also explains the existence of nearly twenty different systems throughout the country, with their own specific procedures.

Similarly, mediation is also influenced by legislative changes. We have previously seen how the new regulation for collective bargaining has changed the traditional balance between parties, in such that the relative power that once belonged to the unions now has shifted to the employers. In the following years this may mean that the collective agreements reached at organizational level will increase, while those at sectorial and regional level will decrease. 
In the same way, the traditional lack of trust between unions and employers has motivated the existence of mediation systems in which the parties take part of (and act as mediators, as we have seen before), with an important supervision of the systems from both sides.

All the public systems of mediation for collective conflicts are financially supported by the public administrations. However the management and decision-making is in the hands of the employers' and unions' side, with the support of the labor administration. These relations explain this unique model of participative mediation. The relations between the parties also influence the mediation systems significantly, following the 3-R model once again (Bollen et al., 2016).

Finally, there is a crucial change that is taking place, worth mentioning, regarding the expectations of the parties about the role of the mediators, demanding a higher application of techniques and strategies of conflict resolution, more professionalized inside the mediation systems. This requires more appropriate selection, training and evaluation methods for mediators, as well as effective evaluations of the systems, to improve the systems' capacity to contribute to social dialogue, as suggested by the 3-R model in relation to the roles' dimension.

\section{References}

Bollen, K., \& Euwema, M. (2013). Workplace mediation: An underdeveloped research area. Negotiation Journal, 29(3), 329-353.

Bollen, K., Euwema, M., \& Munduate, L. (2016). Advancing workplace mediation through integration of theory and practice. London: Springer International Publishing.

CES. (2017). Annual report. Madrid: Consejo Económico y Social.

Elgoibar, P., Munduate, L., Medina, F. J., \& Euwema, M. (2012). Why are industrial relations in Spain competitive? Trust in management, union support and conflict behaviour in worker representatives. Revista Internacional de Organizaciones, 9, 145-168.

Medina, F. J., Vilches, V., Otero, M., \& Munduate, L. (2014). How negotiators are transformed into mediators. Labor conflict mediation in Andalusia. Revista de Psicología del Trabajo y de las Organizaciones, 30, 3-25.

Miguélez, F., \& Prieto, C. (2009). Trasformaciones del empleo, flexibilidad y relaciones laborales en Europa/ Transformations of employment, flexibility and industrial relations in Europe. Política y sociedad, 46(1-2), 275.

Munduate, L. (1993). A psychosocial approach to the study of conflict and negotiation in Spain: A review. Psicothema, 5, 261-275.

Munduate, L., Butts, T., Medina, F., \& Martínez-Pecino, R., (2014). Manual para la mediación laboral. Sevilla: Consejo Andaluz de Relaciones Laborales (CARL).

Munduate, L., Ganaza, J., Alcaide, M., \& Peiró, J. M. (1994). Spain. In M. A. Rahim \& A. A. Blum (Eds.), Global perspectives on organizational conflict. Connecticut: Praeger.

Sánchez-Cuenca, I., \& Aguilar, P. (2009). Terrorist violence and popular mobilization: The case of the Spanish transition to democracy. Politics \& Society, 37(3), 428-453.

SERCLA (2014). Sistema Extrajudicial de Resolución de Conflictos Laborales de Andalucía. Carta de Compromisos de la Actuación Mediadora 2014 [Extrajudicial system for labor conflict resolution in Andalusia. Report 2014]. Sevilla: Consejo Andaluz de Relaciones Laborales.

SIMA. (2017). Annual report. Madrid: Servicio Interconfederal de Mediación y Arbitraje. 
Slaikeu, K. A. (1996). When push comes to shove. A Practical Guide to Mediating Disputes. Boston, MA: Jossey-Bass.

Ury, W. L., Brett, J. M., \& Goldberg, S. B. (1988). Getting disputes resolved: Designing systems to cut the costs of conflict. Boston, MA: Jossey-Bass.

Open Access This chapter is licensed under the terms of the Creative Commons Attribution 4.0 International License (http://creativecommons.org/licenses/by/4.0/), which permits use, sharing, adaptation, distribution and reproduction in any medium or format, as long as you give appropriate credit to the original author(s) and the source, provide a link to the Creative Commons license and indicate if changes were made.

The images or other third party material in this chapter are included in the chapter's Creative Commons license, unless indicated otherwise in a credit line to the material. If material is not included in the chapter's Creative Commons license and your intended use is not permitted by statutory regulation or exceeds the permitted use, you will need to obtain permission directly from the copyright holder.

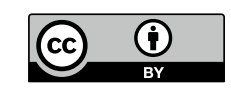

